Original Research Paper

\title{
Career Maturity of Students with Visual Impairment in Relation to their Self Efficacy and Self Advocacy
}

\author{
${ }^{1}$ Kaur Supreet and ${ }^{2}$ Juneja Mamta \\ ${ }^{I}$ Department of Education, USOL, P.U. Chandigarh, India \\ ${ }^{2}$ Department of Education, P.U. Chandigarh, India
}

Article history

Received: 04-04-2017

Revised: 01-07-2017

Accepted: 6-01-2018

Corresponding Author:

Kaur Supreet

Department of Education,

USOL, P.U. Chandigarh, India

Email: supreet10000@gmail.com

\begin{abstract}
The study investigated relationship of career maturity with career decision self-efficacy and self-advocacy of the students with visual impairment. Mixed method approach employed for the study. Purposive sampling technique was employed, a sample of 100 students were taken for study. The main finding are: There is a significant relationship between career maturity (competence test) and career decision making self-efficacy of the students with visual impairment. There is a significant relationship between career maturity (self-appraisal, occupational information, goal selection, problem solving) and self-advocacy of the students with visual impairment. There is no significant gender difference on career maturity of students with visual impairment. Career decision making self-efficacy and self- advocacy were found to be the predictors of career maturity (self-appraisal, goal selection, planning) and contribute significantly to career maturity (self-appraisal, goal selection, planning) of students with visual impairment. Career decision making self-efficacy was found the predictors of career maturity (occupational information, problem solving) and contribute significantly to career maturity (occupational information, problem solving) of students with visual impairment. There are various factors such as socioeconomic status, uneducated parents, knowledge of braille etc. which contributed to low career maturity of the students with visual impairment.
\end{abstract}

Keywords: Career Maturity, Self-Efficacy, Self-Advocacy, Visual Impairment

\section{Introduction}

The social organization of any society depends greatly on the career development of individuals. This is assumed that by the end of high school, adolescents have sufficient knowledge about the world of work and they are in a position to make a career choice (Coertse and Schepers, 2004). Individuals with disabilities have a more hard career development process than their peers and are more receptive to vocational identity and career decision-making problems. There are a number of factors that influence the career decision making process for people with disabilities. Individual factors are, gender cultural background, socioeconomic status, self-esteem, selfefficacy (Szymanski and Hershenson, 1998) and disability status. Environmental factors are family involvement, work experiences (Blustein et al., 2000;
Ohler et al., 1996) and decision-making opportunities (Hagner and Salomone, 1989) have been found to affect the career decision-making abilities of individuals with disabilities. Individuals with disabilities should have an understanding of their disabilities and they can advocate for themselves (Mellard and Hazel, 1992; Minskoff, 1994).

The World Health Organization has clearly distinguished the use of three terms: Impairment, disability and handicap. Impairment means, abnormalities of body structure and functions of organ or organ system. Impairment means problems at organ level. Disability considers the results of impairment in terms of functional performance of organs and activity by the individual. Handicap refers to disadvantages faced by the individual as a result of impairments and disabilities; so handicaps reflect the interaction of adjustment of individual with his surroundings (WHO, 1976). 


\section{Vision Impairment}

Visual handicap is defined in terms of visual sensitivity, ability to see and visual efficiency. Visual ability is the ability of the eye to see distant as well as nearby objects clearly using Snellen chart. Individuals who see the letter ' $E$ ' from a 20 feet distance instead of 200 feet are legally blind. Low vision or residual vision children are sighted and their visual sensitivity does not exceed 20/70. These children have coordination and mobility problems. The causes of blindness can be both genetic and environmental. Students with visual impairment have problems in reading, viewing boards, overheads, videos and other visual demonstrations. They have difficulties in getting around the campus as well as find places or materials in classrooms.

\section{Career Maturity}

Career maturity can be defined as an individual's readiness to make informed career choices and decisions, which are both, realistic and age-appropriate (Savickas, 1984). Career maturity means knowledge of professional behaviour. Therefore, in career development process career maturity plays an important role in influencing the career decision-making (Creed et al., 2006). Career maturity is an area to which an individual is able to acquire those career developmental tasks which are suitable to the appropriate stage of his/her life (Miles, 2008). Therefore, career maturity can be a useful measure with individuals with disabilities. Because they can perform according to their ability.

\section{Dimensions of Career Maturity}

There are two dimensions of career maturity (Crites, 1976):

\section{- Attitudinal \\ - Cognitive}

\section{Attitudinal}

The attitudinal dimension refers to attitudes and emotions of the individual about making a career choice and whether they enable to continue their career choice as they engage in the occupation. Career-related orientation, involvement, planning and exploration have been defined as representing career attitudes or career behaviours (Schimitt-Rodermund and Silbereisen, 1998).

\section{Cognitive}

The cognitive dimension refers to individuals' awareness to make a career choice and their understanding in other career possibilities. It consists of information which refers to the knowledge and competencies required to make career decisions, which include occupational information, self-appraisal and planning (Creed and Patton, 2003). For students with disabilities, the cognitive dimension is significant in their career decision making process. These students face cognitive challenges of selecting a career, finishing college and finding employment.

\section{Career Decision Making Self-Efficacy}

According to Taylor and Betz (1983) career decision making self-efficacy is an individual's belief that he or she can successfully complete task indispensable to career decision making. Career decision making selfefficacy is an individual's beliefs that he or she can perform the activities and obligations correctly to make a powerful career decision (Gati and Amir, 2006)

\section{Self-Advocacy}

Balcazar et al. (1996) defined, "Self-advocacy is a assertion by people with developmental disabilities that they want to be seen as people who have something to offer and skills to share, rather than be seen as people with handicaps or limitations. Self-advocacy influences one's ability to preserve an independent standard of living. It impacts one's achievements within the school and the community. Particularly for students with disabilities, communicating rights and requesting appropriate accommodations have been areas of weakness (Swanson, 2008). Self-Advocacy refers to skills one uses to communicate, express needs and desires or state his or her own interests, to gain access to their needs and rights (Van Reusen et al., 2015).

\section{Rational of the Study}

The main idea to pursue the present piece of work is to study career maturity of students with visual impairment in relation to their career decision making self- efficacy and self-advocacy. The selection of an occupation is one of the most important decisions for an adolescent. These days a large number of career options are available to the students, therefore it is a difficult task for the individuals to make a mature choice. Students with visual impairment face many challenges in their career decision making process and in school-to-work transition. They face environmental and behavioral barrier that can impede their achievement of advancement in their career development.

\section{Delimitations}

The study under investigation was delimited to the following: 
- The study was delimited to special schools of Delhi and Chandigarh only

- The study was delimited to age group from 14-22 years of the students with visual impairment

- The study was further delimited to one type of disability i.e., visual impairment

\section{Objectives}

The specific objectives of the study were:

- To study the nature of the variables under study viz. career maturity, career decision making self-efficacy and self-advocacy in the students with visual impairment

- To study the relationship of the career maturity with career decision making self- efficacy of the students with visual impairment

- To study the relationship of the career maturity with self- advocacy of the students with visual impairment

- To find out whether boys and girls with visual impairment exhibit any differences with regards to their career maturity

- To find out the predictors of career maturity from among the independent variable of career decision making self-efficacy and self-advocacy of the students with visual impairment

\section{Hypotheses}

Based on above mentioned objectives following hypotheses have been framed:

\section{$H_{1}$}

- There exists no significant relationship between the sub dimension of career maturity (self-appraisal) and career decision making self-efficacy of students with visual impairment

- There exists no significant relationship between the sub dimension of career maturity (occupational information) and career decision making selfefficacy of students with visual impairment

- There exists no significant relationship between the sub dimension of career maturity (goal selection) and career decision making self-efficacy of students with visual impairment

- There exists no significant relationship between the sub dimension of career maturity (planning) and career decision making self-efficacy of students with visual impairment

- There exists no significant relationship between sub dimension of career maturity (problem solving) and career decision making self-efficacy of students with visual impairment
- There exists no significant relationship between dimension of career maturity (attitude scale) and career decision making self-efficacy of students with visual impairment

$\mathrm{H}_{2}$

- There exists no significant relationship between sub dimension of career maturity (self-appraisal) and self-advocacy of students with visual impairment

- There exists no significant relationship between sub dimension of career maturity (occupational information) and self-advocacy of students with visual impairment

- There exists no significant relationship between sub dimension of career maturity (goal selection) and self-advocacy of students with visual impairment.

- There exists no significant relationship between the sub dimension of career maturity (planning) and self-advocacy of students with visual impairment.

- There exists no significant relationship between the sub dimension of career maturity (problem solving) and self- advocacy of students with visual impairment

- There exists no significant relationship between the dimension of career maturity (attitude scale) and self-advocacy of students with visual impairment

$H_{3}$

- There exists no significant gender difference in the sub dimension of career maturity (self-appraisal) of students with visual impairment

- There exists no significant gender difference in the sub dimension of career maturity (occupational information) of students with visual impairment

- There exists no significant gender difference in the sub dimension of career maturity (goal selection) of students with visual impairment

- There exists no significant gender difference in the sub dimension of career maturity (planning) of students with visual impairment

- There exists no significant gender difference in the sub dimension of career maturity (problem solving) of students with visual impairment

- There exists no significant gender difference in the dimension of career maturity (attitude scale) of students with visual impairment

$\mathrm{H}_{4}$

- None of the independent variable of career decision making self-efficacy and self-advocacy would contribute significantly in predicting the 
career maturity (self-appraisal) independently as well as conjointly among the students with visual impairment

- None of the independent variable of career decision making self-efficacy and self-advocacy would contribute significantly in predicting the career maturity (occupational information) independently as well as conjointly among the students with visual impairment

- None of the independent variable of career decision making self-efficacy and self-advocacy would contribute significantly in predicting the career maturity (goal selection) independently as well as conjointly among the students with visual impairment

- None of the independent variable of career decision making self-efficacy and self-advocacy would contribute significantly in predicting the career maturity (planning) independently as well as conjointly among the students with visual impairment

- None of the independent variable of career decision making self-efficacy and self-advocacy would contribute significantly in predicting the career maturity (problem solving) independently as well as conjointly among the students with visual impairment

- None of the independent variable of career decision making self-efficacy and self-advocacy would contribute significantly in predicting the career maturity (attitude scale) independently as well as conjointly among the students with visual impairment

\section{Method and Procedure}

The method of the study was designed to best address the research questions through a combination of quantitative and qualitative approaches in a sequential manner. The mixed methods study in which one method is used to further explore and expand the findings of another (Creswell, 2003; Tashakkori and Teddlie, 1998).

\section{Quantitative Descriptive Phase}

The purpose of this phase of the research study to collect quantitative data through survey instruments from the students with visual impairment studied in special schools of Delhi and Chandigarh. Exploratory descriptive survey method was employed in this study. The study was completed in two phases. In first phase, the tool i.e., self-advocacy questionnaire was constructed and validated by the investigator. In the second phase the data was collected, analyzed and interpreted. A sample of 100 respondents (62 boys and 38 girls) was selected using purposive sampling. This sample was consisted of students with visual impairment, studying in different special schools was taken for study. Out of which 50 students from
National confederation of blind (Rohini) and 50 students from National confederation of blind (Chandigarh) was taken for study.

\section{Tool Used}

- Career maturity inventory (CMI, Gupta, 1989) was used

- Career decision making self-efficacy- short form (CDSE-SF; Betz, Klein and Taylor, 1996) was used.

- Self-advocacy questionnaire developed by investigator herself

\section{Statistical Techniques Used}

For the analysis of data following statistical techniques were used:

- Descriptive statistical techniques such as mean, standard deviation, skewness and kurtosis were worked out to ascertain nature of the distribution of the scores on the dependent variables career maturity and its dimensions and independent variable of career decision making self-efficacy and self- advocacy

- Pearson's Product Method was used to compute correlation of the career maturity and its dimensions with career decision making self-efficacy and selfadvocacy

- $\quad$ t-ratio was employed to find out the gender differences on the career maturity and its dimensions

- Step-wise multiple regression analysis was done to find out the predictors (contributors) of criterion variable career maturity and its dimensions from among the independent variables of career decision making self-efficacy and self-advocacy

\section{Qualitative Phase}

As qualitative studies depends on collecting data from participants in their natural settings and most of the data are usually without numbers, unstructured text data, a high level of language skills are required. In terms of selecting the students for interviews, the researcher first and foremost used their career maturity score as selection criterion. Researcher selected those students who had low score on career maturity scale. The interview was semi-structured. Each participant was asked the same question during the interview. For the quantitative phase of the study, the sample comprised of 4 students with visual impairment. The data for this study was collected through in-depth interviews and observations. All interviews were conducted at the convenience of the participants. Notes were taken to obtain relevant information. 


\section{Analysis and Interpretation of the Results}

- Analysis of descriptive statistics for the students with visual impairment

- Correlation of career maturity with career decision making self-efficacy and self-advocacy for the students with visual impairment

- Gender difference for the students with visual impairment on career maturity

- Regression Analysis for students with visual impairment

- Factors contributing to low career maturity of the students with visual impairment

\section{Analysis of Descriptive Statistics for Students with Visual Impairment}

The mean, S.D., Sk and Ku of the variables under study i.e., career maturity, career decision making selfefficacy, self- advocacy, in case of students with visual impairment has been given in Table 1 .

\section{Career Maturity}

The variable of career maturity includes two types of measures i.e., attitude scale and competence test. The attitude scale measures the conative aspects of decisionmaking. The competence test measures the cognitive variables in choosing a vocation. In all there are five parts of the competence test (Self-appraisal; Occupational information; Goal selection; Planning; Problem solving).

\section{Competence Test}

\section{Self-Appraisal}

Table 1 reveals that for the students with visual impairment, the mean and S.D. of career maturity (selfappraisal) were 6.47 and 2.01 respectively. The value of mean and S.D. were average. This depicts that students had average ability to accurately appraise their own strengths related to career decision. Sk is found to be 0.59 which is negative and shows that the distribution is negatively skewed. Ku is- 0.073 which is lesser than $\mathrm{Ku}$ for normal curve and shows that curve is leptokurtic.

\section{Occupational Information}

Table 1 reveals that for the students with visual impairment, the mean and S.D. of career maturity (occupational information) were 8.61 and 1.96 respectively. The value of mean and S.D. were average. It reveals that students had average ability to locate various sources of information about college majors and occupations. Sk is found to be -0.71 which is negative and shows that the distribution is negatively skewed. $\mathrm{Ku}$ is 1.420 which is greater than $\mathrm{Ku}$ for normal curve and shows that curve is platykurtic.

\section{Goal Selection}

Table 1 reveals that for the students with visual impairment, the mean and S.D. of career maturity (goal selection) were 8.39 and 2.06 respectively. The mean was found to be high as per norms. It reveals that students had high ability to match one's own characteristics to the demands of careers. Sk was found to be -0.87 which is negative and shows that the distribution is negatively skewed. $\mathrm{Ku}$ is 0.706 which is greater than $\mathrm{Ku}$ for normal curve and shows that curve is platykurtic.

\section{Planning}

Table 1 reveals that for the students with visual impairment, the mean and S.D. of career maturity (planning) were 9.29 and 2.35 respectively. The mean was found to be high as per norms. It depicts that students had high tendency to think about various means, which were necessary to attain desired end. It reveals that $\mathrm{Sk}$ is found to be -0.94 which is negative and shows that the distribution is negatively skewed. $\mathrm{Ku}$ is 1.325 which is greater than $\mathrm{Ku}$ for normal curve and shows that curve is platykurtic.

\section{Problem Solving}

Table 1 reveals that for the students with visual impairment, the mean and S.D. of career maturity (problem solving) were 6.33 and1.80 respectively. The mean was found to be high as per norms. It reveals that students possessed high capability in solving problems that arise in the process of decision making. Sk is found to be -0.38 which is negative and shows that the distribution is negatively skewed. $\mathrm{Ku}$ is -0.625 which is lesser than $\mathrm{Ku}$ for normal curve and shows that curve is leptokurtic.

Table 1: A summary of descriptive statistics of different variables for students with visual impairment $(\mathrm{N}=100)$

\begin{tabular}{|c|c|c|c|c|c|}
\hline Variables & Mean & S.D. & Sk & $\mathrm{Ku}$ & Remarks \\
\hline \multicolumn{6}{|l|}{ Career maturity } \\
\hline \multicolumn{6}{|l|}{ Competence Test } \\
\hline Self-appraisal & 6.47 & 2.01 & -0.59 & -0.073 & Average \\
\hline Occupational information & $8 . .61$ & 1.96 & -0.71 & 1.420 & Average \\
\hline Goal selection & 8.39 & 2.06 & -0.87 & 0.706 & High \\
\hline Planning & 9.29 & 2.35 & -0.94 & 1.325 & High \\
\hline Problem solving & 6.33 & 1.80 & -0.38 & -0.625 & High \\
\hline Attitude scale & 26.72 & 3.15 & -0.09 & 0.959 & Low \\
\hline Career decision making self- efficacy & 94.09 & 17.31 & -0.87 & 4.090 & Average \\
\hline Self-advocacy & 27.85 & 3.72 & -0.72 & -.464 & Average \\
\hline
\end{tabular}




\section{Attitude Scale}

Table 1 reveals that for the students with visual impairment, the mean and S.D. of career attitude of career maturity were 26.72 and 3.15 respectively. The mean was found to be low as per norms. The low score indicate that students with visual impairment had less developed attitude towards career decisions. Sk is found to be -0.09 which is negative and shows that the distribution is negatively skewed. $\mathrm{Ku}$ is 0.959 which is greater than $\mathrm{Ku}$ for normal curve and shows that curve is platykurtic.

\section{Career Decision Making Self Efficacy}

Table 1 shows that for the students with visual impairment, the value of mean and S.D. of career decision making self-efficacy was 94.09 and 17.31 respectively. The value of mean and S.D. were average. This depicts that students with visual impairment can complete tasks necessary to make career decisions. Sk is found to be -0.87 which is negative and showed that the data is negatively skewed. $\mathrm{Ku}$ is 4.090 which is greater than $0.263 \mathrm{ku}$ for normal curve and exhibits that the curve is platykurtic.

\section{Self-Advocacy}

Table 1 shows the value of mean and S.D. of selfadvocacy for the students with visual impairment, were 27.85 and 3.72 respectively. The value of mean and S.D. were average. This reveals that students with visual impairment understand their disability and were aware of their strengths and weaknesses. Sk is found to be -0.72 which is negative and showed that the data is negatively skewed. $\mathrm{Ku}$ is -0.464 which is lesser than $0.263 \mathrm{ku}$ for normal curve and exhibits that the curve is leptokurtic.

\section{Analysis of Correlation}

\section{Correlation of Career Maturity with Career Decision Making Self- Efficacy}

Table 2 shows the correlation of dimensions of career maturity (competence and attitude) with the career decision making self-efficacy viz self-appraisal, occupational information, goal selection, planning and problem solving and attitude scale are $0.443,0.467$, $0.384,0.432,0.340,0.037$ respectively. These values $0.443,0.467,0.384,0.432,0.340$ are more than the table value of 0.254 at 0.01 level of significance and hence significant at 0.01 level of significance. No significant correlation is found between dimension of career maturity (attitude scale $=0.037$ ) and career decision making selfefficacy. Thus there exists a significant relationship between dimension of career maturity (competence test) and career decision making self-efficacy.

Correlation of sub Dimension of Career Maturity (Self-Appraisal) with Career Decision Making Self Efficacy

Table 2 shows that the significant relationship is found between sub dimension of career maturity (self-appraisal) and career decision making self-efficacy (0.443) at 0.01 level, for the students with visual impairment. Hence, the hypothesis $\mathrm{H}_{1}$ (i) there exists no significant relationship between self-appraisal and career decision making selfefficacy for the students with visual impairment, is not accepted. The result shows that self-appraisal contributes towards career decision making self -efficacy. Above result also depicts that students who were more confident in studying their own abilities, talents and potentialities faced lesser difficulties in decision making.

\section{Correlation of sub Dimension of Career Maturity (Occupational Information) with Career Decision Making Self Efficacy}

Table 2 reveals that significant relationship is found between sub dimension of career maturity (occupational information) and career decision making self-efficacy $(0.467)$ at 0.01 level, for the students with visual impairment. Hence, the hypothesis $\mathrm{H}_{1}$ (ii) there exists no significant relationship between sub dimension of career maturity (occupational information) and career decision making self-efficacy for the students with visual impairment, is not accepted. The result reveals that students who were able to collect occupational information from various sources, could progress in the career decision-making process.

Table 2: Correlation matrix of the variable career maturity and career decision making self-efficacy and self-advocacy for students with visual impairment $(\mathrm{N}=100)$

\begin{tabular}{|c|c|c|c|c|c|c|c|c|}
\hline Variables & $\begin{array}{l}\text { Self- } \\
\text { appraisal }\end{array}$ & $\begin{array}{l}\text { Occupational } \\
\text { information }\end{array}$ & $\begin{array}{l}\text { Goal } \\
\text { selection }\end{array}$ & Planning & $\begin{array}{l}\text { Problem } \\
\text { solving }\end{array}$ & Attitude scale & $\begin{array}{l}\text { Career decision } \\
\text { making self efficacy }\end{array}$ & $\begin{array}{l}\text { Self- } \\
\text { advocacy }\end{array}$ \\
\hline \multicolumn{9}{|l|}{ Career Maturity } \\
\hline Competence test & & & & & & & & \\
\hline Self-appraisal & 1 & & & & & & & \\
\hline Occupational-information & $0.619^{* *}$ & 1 & & & & & & \\
\hline Goal selection & $0.567^{* *}$ & $0.607^{* *}$ & 1 & & & & & \\
\hline Planning & $0.623^{* *}$ & $0.695^{* *}$ & $0.804^{* *}$ & 1 & & & & \\
\hline Problem solving & $0.593^{* *}$ & $0.535^{* *}$ & $0.637^{* *}$ & $0.685^{* *}$ & 1 & & & \\
\hline Attitude scale & $0.221^{*}$ & 0.168 & 0.071 & 0.045 & 0.134 & 1 & & \\
\hline Career decision making self efficacy & $0.443^{* *}$ & $0.467^{* *}$ & $0.384^{* *}$ & $.432 * *$ & $0.340^{* *}$ & 0.037 & 1 & \\
\hline Self advocacy & $0.339^{* *}$ & $0.292^{* *}$ & $0.302^{* *}$ & $0.310^{* *}$ & 0.068 & 0.171 & $0.279^{* *}$ & 1 \\
\hline
\end{tabular}


Correlation of sub dimension of Career Maturity (Goal Selection) with Career Decision Making Self Efficacy

Table 2 shows that significant relationship is found between sub dimension of career maturity (goal selection) and career decision making self-efficacy $(0.384)$ at 0.01 level, for the students with visual impairment. $\mathrm{H}_{1}$ (iii) there exists no significant relationship between sub dimension of career maturity (goal selection) and career decision making self-efficacy for the students with visual impairment, is not accepted. The result reveals that students were able to select a goal suitable to their capacities in decision making.

Correlation of sub Dimension of Career Maturity (Planning) with Career Decision Making Self Efficacy

Table 2 shows that significant relationship is found between sub dimension of career maturity (planning) and career decision making self-efficacy (0.432) at 0.01 level, for the students with visual impairment. Hence, the hypothesis $\mathrm{H}_{1}$ (iv) there exists no significant relationship between sub dimension of career maturity (planning) and career decision making self-efficacy for the students with visual impairment, is not accepted. The result demonstrates that students, who were able to make and execute plans, faced less difficulty in career decision making.

Correlation of sub Dimension of Career Maturity (Problem Solving) with Career Decision Making Self Efficacy

Table 2 shows that significant relationship is found between sub dimension of career maturity (problem solving) and career decision making self-efficacy $(0.340)$ at 0.01 level, for the students with visual impairment. Hence, the hypothesis $\mathrm{H}_{1}(\mathrm{v})$ there exists no significant relationship between career maturity (problem solving) and career decision making self-efficacy for the students with visual impairment, is not accepted. The result depicts that individuals with higher problem-solving skills were more confident in their decision-making ability and career potential and more certain about their educational and career choice.

It is clear from above discussion that out of six dimensions of career maturity correlation is found on five dimensions namely self-appraisal, occupational information, goal selection, planning and problem solving with career decision making self-efficacy for the students with visual impairment. These findings are supported by Barker and Kellen (1998) who found that one of the most important tasks that one undertakes as part of the career decision making process is to collect information about the possible career options that one is interested in. These finding are also supported by Powell and Luzzo (1998) who found that those who had more personal control over their career decisions had more positive attitudes toward career decision-making and were more career aware.

\section{Correlation of Career Maturity with Self advocacy}

The correlation between variables has been presented as under.

Table 2 shows the correlation of self-advocacy and sub dimensions of career maturity viz. self-appraisal, occupational information, goal selection, planning, problem solving and attitude scale are $0.339,0.292,0.302$, $0.310,0.068$ and 0.171 respectively. These values 0.339 , $0.292,0.302,0.310$ are more than the table value of 0.254 at 0.01 level of significance and hence significant at 0.01 level of significance. No significant relationship is found between problem solving $(0.068)$ sub dimension of career maturity and self-advocacy, attitude (0.171) dimension of career maturity and self-advocacy. Thus, there exists significant relationship between sub dimensions of career maturity i.e., self-appraisal, occupational information, goal selection and planning with self-advocacy.

\section{Correlation of Sub Dimension of Career Maturity} (Self-Appraisal) with Self Advocacy

Table 2 shows that significant relationship is found between sub dimension of career maturity (selfappraisal) and self-advocacy (0.339) at 0.01 level, for the students with visual impairment. Hence, the hypothesis $\mathrm{H}_{2}$ (i) there exists no significant relationship between sub dimension of career maturity (self-appraisal) and selfadvocacy for the students with visual impairment, is not accepted. It means self-appraisal contributes towards self-advocacy. The students who were aware about their disability could choose better career for themselves.

\section{Correlation of Sub Dimension of Career Maturity (Occupational Information) with Self Advocacy}

Table 2 shows that significant relationship is found between sub dimension of career maturity (occupational information) and self-advocacy (0.0292) at 0.01 level, for the students with visual impairment. Hence, the hypothesis $\mathrm{H}_{2}$ (ii) there exists no significant relationship between sub dimension of career maturity (occupational information) and self-advocacy for the students with visual impairment, is not accepted. It means that the students with disabilities who can understand their strengths and weaknesses were able to obtain information about various occupations.

\section{Correlation of Sub dimension of Career Maturity (Goal Selection) with Self Advocacy}

Table 2 shows that significant relationship is found between sub dimension of career maturity (goal selection) and self-advocacy (0.302) at 0.01 level, for the students with visual impairment. Hence, the hypothesis $\mathrm{H}_{2}$ (iii) there exists no significant relationship between career 
maturity (goal selection) and self-advocacy for the students with visual impairment, is not accepted. The result demonstrates that students who were aware about their strengths, weaknesses and disability rights were able to obtain their goal.

\section{Correlation of Sub Dimension of Career Maturity (Planning) with Self Advocacy}

Table 2 shows that significant relationship is found between sub dimension of career maturity (planning) and self-advocacy (0.310) at 0.01 level, for the students with visual impairment. Hence, the hypothesis $\mathrm{H}_{2}$ (iv) there exists no significant relationship between career maturity (planning) and career decision making self-efficacy for the students with visual impairment, is not accepted. The above result depicts that self-advocacy strategies helped the students to function more independently by identifying their areas of weakness and accessing resources to meet goals.

It is clear from above discussions that out of six dimensions of career maturity, correlation is found on four dimensions namely self-appraisal, occupational information, goal selection, planning with selfadvocacy for the students with visual impairment. The finding are supported by Luzzo (1995) that the students with hearing, visual, or physical disabilities were better able to describe the impact of their disability on academic and career development than were students with other types of disabilities. The students with disabilities, who participate in self-advocacy training, can develop individualized career plans.

\section{Gender Differences on Career Maturity for the Students with Visual Impairment}

\section{Discussion Based on Table 3}

Significance of differences between means of boys and girls on the variable of career maturity along with six sub-variables of CMI was computed by t-ratios with a view to examine the gender differences (Table 4). All mean differences presented in Table 4 are insignificant between the boys and girls on various dimensions of career maturity, namely, self-appraisal $(\mathrm{t}=-0.31)$, occupational information $(\mathrm{t}=-0.29)$, goal selection $(\mathrm{t}=$ $0.18)$, planning $(\mathrm{t}=0.61)$, problem solving $(\mathrm{t}=0.53)$, attitude scale (sub test) $(\mathrm{t}=0.40)$.

\section{Regression Analysis for Students with Visual Impairment}

Table 4 shows that the F-value for this step is 6.44 which is significant at 0.05 level. This demonstrates that increase in the prediction value after the addition of self-advocacy is significant. In present study career decision making self-efficacy and self-advocacy contributes conjointly as well as independently towards the prediction of career maturity (self-appraisal). Thus the null hypothesis $\mathrm{H}_{4}$ (i) that none of the independent variable of career decision making self-efficacy and self-advocacy would contribute significantly in predicting the career maturity (self-appraisal) independently as well as conjointly among students with visual impairment, is not accepted.

Table 5 shows that the F-value for this step was 27.38 which is significant at 0.01 level. This demonstrates that career decision making self-efficacy was significantly predictor of criterion variable i.e., career maturity (occupational information) of the students with visual impairment. Thus the null hypothesis $\mathrm{H}_{4}$ (ii) that none of the independent variable of career decision making self-efficacy and self-advocacy would contribute significantly in predicting the career maturity (occupational information) independently as well as conjointly among students with visual impairment, is not accepted in the present investigation.

From the Table 3 It is clear that out of six dimensions of career maturity, no significant gender difference was observed in case of students with visual impairment. These findings are also supported by Salami (2008) who demonstrated that no significant differences were found between the males and females in their career maturity.

Table 3: Comparison of boys $(\mathrm{N}=62)$ and girls $(\mathrm{N}=38)$ with visual impairment on the variables of career maturity.

\begin{tabular}{|c|c|c|c|c|c|c|c|}
\hline Variables & $\begin{array}{l}\text { Boys } \\
\text { Mean }\end{array}$ & S.D. & $\begin{array}{l}\text { Girls } \\
\mathrm{SE}_{\mathrm{M}}\end{array}$ & Mean & S.D. & $\mathrm{SE}_{\mathrm{M}}$ & t-ratio \\
\hline \multicolumn{8}{|l|}{ Career maturity } \\
\hline \multicolumn{8}{|l|}{ Competence Tes } \\
\hline Self-appraisal & 6.42 & 2.16 & 0.276 & 6.55 & 1.76 & 0.286 & -0.319 \\
\hline Occupational information & 8.56 & 2.05 & 0.261 & 8.68 & 1.84 & 0.300 & -0.294 \\
\hline Goal selection & 8.42 & 2.01 & 0.256 & 8.34 & 2.17 & 0.352 & 0.181 \\
\hline Planning & 9.40 & 2.30 & 0.292 & 9.11 & 2.46 & 0.401 & 0.611 \\
\hline Problem solving & 6.41 & 1.68 & 0.216 & 6.21 & 1.98 & 0.323 & 0.533 \\
\hline Attitude scale 26.63 & 3.36 & 0.427 & 26.87 & 2.80 & 0.454 & $0-.367$ & \\
\hline
\end{tabular}

*Significant at 0.05 level (1.98); **Significant at 0.01 level (2.63) 
Table 4: Step-wise multiple regression equation for sub dimension of Career maturity (self-appraisal) for the students with visual impairment $(\mathrm{N}=100)$

\begin{tabular}{|c|c|c|c|c|c|c|c|c|c|}
\hline \multirow[b]{2}{*}{ Model } & \multirow[b]{2}{*}{$\mathrm{R}$} & \multirow[b]{2}{*}{ R Square } & \multirow[b]{2}{*}{$\begin{array}{l}\text { Adjusted } \\
\text { R Square. }\end{array}$} & \multirow[b]{2}{*}{$\begin{array}{l}\text { Std. Error } \\
\text { of Estimate }\end{array}$} & \multicolumn{5}{|c|}{ Change statistics } \\
\hline & & & & & $\begin{array}{l}\text { R square } \\
\text { change }\end{array}$ & F Change & $\mathrm{D} \mathrm{fl}$ & Df2 & $\begin{array}{l}\text { Sig. F } \\
\text { Change }\end{array}$ \\
\hline 1 & $0.443^{\text {(b) }}$ & 0.196 & 0.188 & 1.818 & 0.196 & $23.955^{* *}$ & 1 & 98 & .000 \\
\hline 2 & $0.496^{(\mathrm{c})}$ & 0.247 & 0.231 & 1.769 & 0.050 & $6.447 *$ & 1 & 97 & .013 \\
\hline
\end{tabular}

**Significant at 0.01 level; * Significant at 0.05 level; a. (Critical value 3.95 at 0.05 and 6.90 at 0.01 level of df 98 ); b. Predictor: (constant), CDMSE; c. Predictor: (Constant), CDMSE, SA

Table 5: Step-wise multiple regression equation for sub dimension of career maturity (occupational information) for the students with visual impairment $(\mathrm{N}=100)$

\begin{tabular}{|c|c|c|c|c|c|c|c|c|c|}
\hline \multirow[b]{2}{*}{ Model } & \multirow[b]{2}{*}{$\mathrm{R}$} & \multirow[b]{2}{*}{ R Square } & \multirow{2}{*}{\multicolumn{2}{|c|}{ Adjusted Std. Error }} & \multicolumn{5}{|c|}{ Change statistics } \\
\hline & & & & & $\begin{array}{l}\text { R square } \\
\text { change }\end{array}$ & F Change & $\mathrm{d} f 1$ & $\mathrm{~d} f 2$ & $\begin{array}{l}\text { Sig. F } \\
\text { Change }\end{array}$ \\
\hline 1 & $0.467^{(\mathrm{b})}$ & 0.218 & 0.210 & 1.750 & 0.218 & $27.381 * *$ & 1 & 98 & 0.000 \\
\hline
\end{tabular}

**Significant at 0.01 level; *Significant at 0.05 level; a. (Critical value 3.95 at 0.05 and 6.90 at 0.01 level of df 98 ); b. Predictor: (constant), CDMSE

Table 6: Stepwise multiple regression equation for sub dimension of career maturity (goal selection) for the students with visual impairment $(\mathrm{N}=100)$

\begin{tabular}{|c|c|c|c|c|c|c|c|c|c|}
\hline \multirow[b]{2}{*}{ Model } & \multirow[b]{2}{*}{$\mathrm{R}$} & \multirow[b]{2}{*}{ R Square } & \multirow[b]{2}{*}{$\begin{array}{l}\text { Adjusted } \\
\text { R Square }\end{array}$} & \multirow[b]{2}{*}{$\begin{array}{l}\text { Std. Error } \\
\text { of Estimate }\end{array}$} & \multicolumn{5}{|c|}{ Change statistics } \\
\hline & & & & & $\begin{array}{l}\text { R square } \\
\text { change }\end{array}$ & F Change & $\mathrm{d}$ fl & $\mathrm{d}$ f2 & $\begin{array}{l}\text { Sig. F } \\
\text { Change }\end{array}$ \\
\hline 1 & $0.384^{(\mathrm{b})}$ & 0.147 & 0.139 & 1.916 & 0.147 & $16.941 * *$ & 1 & 98 & 0.000 \\
\hline 2 & $0.434^{(\mathrm{c})}$ & 0.188 & 0.172 & 1.879 & 0.041 & $4.910^{*}$ & 1 & 97 & 0.029 \\
\hline
\end{tabular}

**Significant at 0.01 level; *Significant at 0.05 level; a. (Critical value 3.95 at 0.05 and 6.90 at 0.01 level of df 98 ); b. Predictor: (constant), CDMSE; c. Predictor: (Constant), CDMSE, SA

Table 7:Stepwise multiple regression equation for sub dimension of career maturity (planning) for the students with visual impairment $(\mathrm{N}=100)$

\begin{tabular}{|c|c|c|c|c|c|c|c|c|c|}
\hline \multirow[b]{2}{*}{ Model } & \multirow[b]{2}{*}{$\mathrm{R}$} & \multirow[b]{2}{*}{ R Square } & \multirow[b]{2}{*}{$\begin{array}{l}\text { Adjusted } \\
\text { R Square }\end{array}$} & \multirow[b]{2}{*}{$\begin{array}{l}\text { Std. Error } \\
\text { of Estimate }\end{array}$} & \multicolumn{5}{|c|}{ Change statistics } \\
\hline & & & & & $\begin{array}{l}\text { R square } \\
\text { change }\end{array}$ & F Change & $\mathrm{d} \mathrm{fl}$ & $\mathrm{d}$ f2 & $\begin{array}{l}\text { Sig. F } \\
\text { Change }\end{array}$ \\
\hline 1 & $0.432^{\text {(b) }}$ & 0.186 & 0.178 & 2.138 & 0.186 & $22.450 * *$ & 1 & 98 & 0.000 \\
\hline 2 & $0.474^{(\mathrm{c})}$ & 0.225 & 0.209 & 2.097 & 0.039 & $4.850 *$ & 1 & 97 & 0.030 \\
\hline
\end{tabular}

**Significant at 0.01 level; *Significant at 0.05 level; a. (Critical value 3.95 at 0.05 and 6.90 at 0.01 level of df 98); b. Predictor: (constant), CDMSE; c. Predictor: (Constant), CDMSE, SA

Table 6 shows that the F-value for this step is 4.910 which is significant at 0.05 level. This demonstrates that increase in the prediction value after the addition of selfadvocacy is significant. In present study this career decision making self-efficacy and self-advocacy contributes conjointly as well as independently towards the prediction of career maturity (goal selection). Thus, the null hypothesis $\mathrm{H}_{4}$ (iii) that none of the independent variable of career decision making self-efficacy and self-advocacy would contribute significantly in predicting the career maturity (goal selection) independently as well as conjointly among students with visual impairment, is not accepted.
Table 7 shows that the F-value for this step is 4.850 which is significant at 0.05 level. This demonstrates that increase in the prediction value after the addition of selfadvocacy is significant. The career decision making selfefficacy and self-advocacy contributes conjointly as well as independently towards the prediction of career maturity (planning). Thus, the null hypothesis $\mathrm{H}_{4}$ (iv) that none of the independent variable of career decision making self-efficacy and self-advocacy would contribute significantly in predicting the career maturity (planning) independently as well as conjointly among students with visual impairment, is not accepted. 
Table 8: Step-wise multiple regression equation for sub dimension of career maturity (problem solving) for the students with visual impairment $(\mathrm{N}=100)$

\begin{tabular}{|c|c|c|c|c|c|c|c|c|c|}
\hline \multirow[b]{2}{*}{ Model } & \multirow[b]{2}{*}{$\mathrm{R}$} & \multirow[b]{2}{*}{ R Square } & \multirow[b]{2}{*}{$\begin{array}{l}\text { Adjusted } \\
\text { R Square }\end{array}$} & \multirow[b]{2}{*}{$\begin{array}{l}\text { Std. Error } \\
\text { of Estimate }\end{array}$} & \multicolumn{5}{|c|}{ Change statistics } \\
\hline & & & & & $\begin{array}{l}\text { R square } \\
\text { change }\end{array}$ & F Change & $\mathrm{d} \mathrm{fl}$ & $\mathrm{d} \mathrm{f} 2$ & $\begin{array}{l}\text { Sig. F } \\
\text { Change }\end{array}$ \\
\hline 1 & $0.340^{(\mathrm{b})}$ & 0.116 & 0.107 & 1.703 & 0.116 & $12.708 * *$ & 1 & 98 & 0.001 \\
\hline
\end{tabular}

**Significant at 0.01 level; *Significant at 0.05 level; a. (Critical value 3.95 at 0.05 and 6.90 at 0.01 level of df 98 ); b. Predictor: (constant), CDMSE

Table 8 shows that the F-value for this step is 12.708 which is significant at 0.01 level. This demonstrates that career decision making self-efficacy is significantly predictor of career maturity (problem solving) of the students with visual impairment. Thus, the null hypothesis $\mathrm{H}_{4}(\mathrm{v})$ that none of the independent variable of career decision making self-efficacy and selfadvocacy would contribute significantly in predicting the career maturity (problem solving) independently as well as conjointly among students with visual impairment, is not accepted.

\section{Factors Contributing to Low Career Maturity of Students with Visual Impairment}

It is very difficult to educate a person with visual impairment. This is because an individual with visual impairment faced many challenges varying from participation in social activities, locomotion, education, employment etc. It requires lot of money to educate children with visual impairment than their sighted peers. Unlike normal children who can easily learn so many things merely by observing and imitating others, but the child with visual impairment required help for learning so many concepts, thus required more time to be cared for. It is interesting to know that people with visual impairment have the abilities to learn various skills and these skills are useful for them, if they are properly guided by relevant professionals. With these skills the people with visual impairment can live an independent life. The research questions explored possible factors contributing to low career maturity of the students with visual impairment.

\section{Student-I}

Student 1 is 17 years male; his scores on career attitude, self-appraisal, occupational information, goal selection, planning and problem solving were 20, 2, 2, 2, 2,3 . Due to lack of confidence and self-knowledge he could not make decision regarding career choice. Selfknowledge and self-confidence are the primary factors for the students with visual impairment. Self-knowledge means understanding of one's own abilities, character, feelings, or motivations. The student had uneducated parents. Less educated parents are less likely to be involved in their children's education process. Parents play an important role in their children's career decision making process. Parents are important role models for their children (Morrow, 1995). The student belonged to low socioeconomic status. Parents of low-income families participate less in their children's education process. The student also had poor decision-making and problem solving skills because the student did not have experience of part time employment during their secondary school years. The student was not interested in studies and was not getting good marks in the studies. The student did not have knowledge about various occupations. The student had no knowledge about the braille and computer. He was learning braille now, because earlier he was studying in the normal school. When asked from the student what would be his ideal job? He did not respond confidently. He stated that nobody told him that what he should do. It is very difficult for him to decide about his future, because he did not know what he wants to do".

\section{Student-II}

The student- 2 scores on career attitude, selfappraisal, occupational information, goal selection, planning and problem solving were $23,1,2,2,2,3$. Due to lack of confidence and self-knowledge the student could not make decision regarding career choice. Poor self-knowledge makes it difficult for an individual to engage in the career decision-making process altogether. The student had uneducated parents. Less educated parents are less likely to be involved in their children's education process. The family is the most basic institution in our culture and the primary setting where children learn to interact with their environment. The student belonged to low socioeconomic status family. Low SES students have lower levels of career maturity due to lack of occupational information and employment opportunities; (Kerka, 1998). The student also had poor decision-making and problem solving skills as evident from the score, because he did not have experience of part time employment during his secondary school years. He was less likely to have participated in work activities. The student did not have knowledge about various occupations. 
Table 9: Factors contributing to low career maturity of students with visual impairment

\begin{tabular}{|c|c|c|c|c|}
\hline Subject & Subject-1 & Subject-2 & Subject-3 & Subject-4 \\
\hline Father education & Under matric & Under matric & Matric & Under matric \\
\hline Mother education & Under matric & Under matric & Under matric & Under matric \\
\hline $\begin{array}{l}\text { Self- knowledge and } \\
\text { self confidence }\end{array}$ & $\begin{array}{l}\text { Not confident and does } \\
\text { not know his strengths } \\
\text { and weaknesses }\end{array}$ & $\begin{array}{l}\text { Not confident and does } \\
\text { not know his strengths } \\
\text { and weaknesses }\end{array}$ & $\begin{array}{l}\text { Confident and know } \\
\text { about his strength } \\
\text { and weaknesses }\end{array}$ & $\begin{array}{l}\text { Not confident and does } \\
\text { not know his strengths } \\
\text { and weaknesses }\end{array}$ \\
\hline Socio-economic status & Low & Low & Middle & Middle \\
\hline Work experience & No & No & Little knowledge & No \\
\hline Career awareness & No & No & Little awareness & No \\
\hline Pear influence & No & Little & Little & Little \\
\hline Interest in studies & No & No & No & No \\
\hline Computer competence & No & No & Yes & Yes \\
\hline Knowledge of Braille & No & No & Yes & Yes \\
\hline Career attitude & 20 & 23 & 27 & 25 \\
\hline Self-appraisal & 2 & 1 & 3 & 2 \\
\hline Occupational information & 2 & 2 & 6 & 5 \\
\hline Goal selection & 2 & 2 & 5 & 4 \\
\hline Planning & 2 & 2 & 5 & 3 \\
\hline Problem solving & 3 & 3 & 4 & 3 \\
\hline
\end{tabular}

The student did not have knowledge of braille. He was learning braille now. He did not have knowledge of computer. No facilities were available at home. He was not interested in studies and did not get good marks in studies. He stated that he had interest in music. When asked from him he can choose music as a career but he did not respond confidently. He stated that there was no proper guidance provided in the school.

\section{Student-III}

The student 3 scores on career attitude, selfappraisal, occupational information, goal selection, planning and problem solving were $25,3,6,5,5,4$. Student reported that he had not decided about what he would like to do after school. He was not confident about his capabilities. Due to lack of confidence and self- knowledge the student could not make decision regarding career choice. The qualification of his father was matric and he was running his own shop. The student belonged to middle socioeconomic status family. The family is the most basic institution in our culture and the primary setting where children learn to interact with their environment. The student also had poor decision-making and problem solving skills and was less likely to have participated in school activities. This student had little knowledge about various occupations, but he was not aware what kind of job he could do. His father was a shopkeeper, he told that his father often discussed about some occupations, but he had not decided what he would do in the future. The student used braille and had knowledge of computer. He was able to assess the internet in the school but he was not interested in studies. He was getting average marks in his studies. He had interest in music. He stated that normal people think that disabled people cannot do any kind of job.
He was not aware how the subject he learned in the class could be helpful to him in the future (Table 9).

\section{Student-IV}

The student- 4 score on career attitude, selfappraisal, occupational information, goal selection, planning and problem solving were $27,2,5,4,4,3$. Due to lack of confidence and self- knowledge the student could not make decision regarding career choice. The student had less educated parents. Parents maintained an important role in the lives of students with disabilities by encouraging, supporting and understanding them and the issues they face in life. The student had poor decision-making and problem solving skills as evident from the score, because he had less experience of part time employment during his school years. Students with disabilities are less likely to obtain work experiences and therefore do not receive the benefit of having worked. As a result, these students may not have the chance to practice decision-making, problem solving and exploration of different jobs. This student had little knowledge about various occupations. His father was a farmer. He told that his father did not know about various kinds of jobs. He was dependent on school teachers for his studies. The student used braille and had knowledge of computer. He said that he could gather information about some occupations from internet, which were suitable for him but was unable to know how to proceed further.

From the above discussion it reveals that there are various factors which contribute towards the low career maturity of students with visual impairment. Students were not aware about the subjects they had learned in the class could be helpful in the future. Poor selfknowledge regarding one's capabilities, interests or personal traits serve as some of the issues relating to 
lack of information. They had limited information about the occupations and what is involved in these occupations as well as various options that were available; and lack of information about the ways in which one can get career information. Parents maintained an important role in the lives of students with disabilities by encouraging, supporting and understanding them and the issues they face in life. Students feel as if they are not supported, are less likely to be engaged in school and have less positive attitude towards their future careers. Lindstrom et al. (2007) found that family plays an important role in career decision making process and also found that low socioeconomic status has a direct effect on career development and vocational identity. These students depend upon their school teachers for guidance.

\section{Educational Implication of the Study}

- Career maturity levels and career decision-making abilities are very important to people with disabilities. Study reveals that there is a relationship between career maturity and career decision making of the students with visual impairment. This encourages the growth of career maturity in the students through assisting them to obtain employments

- Facilitating informed choice for students by guiding them in the discovery of more detailed information about particular occupations, any potential difficulties their disability may cause in particular occupational roles and potential solutions to these difficulties

- Educating students about the responsibilities of workplaces and institutions of higher education and training to provide necessary accommodations.

- Providing assertiveness training to enable disabled students to confidently and appropriately explain their needs and make requests for accommodations, in job interview situations and in everyday interactions with workmates, colleagues, customers, clients and others

\section{Conclusion}

The present study investigated relationship of career maturity with self-efficacy and self-advocacy among the students with visual impairment. The results show that there exists significant relationship between dimension of career maturity and career decision making selfefficacy of the students with visual impairment. There exists significant relationship between sub dimensions of career maturity and self-advocacy of students with visual impairment. Significant predictors of sub dimensions of career maturity of students with visual impairment were career decision making self-efficacy and self-advocacy.
There were various factors which contributed to low career maturity of students with various types of disabilities. The study would be useful for teachers and administrators to provide appropriate guidance and counseling to develop self-awareness, to enlarge career awareness and to develop appropriate attitude towards work in the students with disabilities.

\section{Author's Contributions}

All authors equally contributed in this work.

\section{Ethics}

This article is original and contains unpublished material. The corresponding author confirms that all of the other authors have read and approved the manuscript and there are no ethical issues involved.

\section{References}

Balcazar, F., C. Keys, J. Bertram and T. Rizzo, 1996. Advocate development in the field of developmental disabilities: A data-based conceptual model. Mental Retardat., 34: 341-351. PMID: 8990818.

Betz, N. E., Klein, K. and Taylor, K. M. (1996). Evaluation of a short form of the Career DecisionMaking Self-Efficacy scale. J. Career Assessment, 4: 47-57.

Barker, J. and J. Kellen, 1998. Career Planning: A Developmental Approach. 1st Edn., Prentice-Hall, Englewood Cliffs, NJ.

Blustein, D.L., C.L. Juntunen and R.L. Worthington, 2000. The School-to-Work Transition: Adjustment Challenges of the Forgotten Half. In: Handbook of Counseling Psychology, Brown, S.D. and R.W. Lent (Eds.), Wiley, New York, pp: 435-470.

Coertse, S. and J.M. Schepers, 2004. Some personality and cognitive correlates of career maturity. South Afr. J. Indust. Psychol., 30: 56-73.

DOI: $10.4102 /$ sajip.v30i2.150

Creed, P.A. and W. Patton, 2003. Predicting two components of career maturity in school based adolescents. J. Career Dev., 29: 277-290.

DOI: $10.1177 / 089484530302900405$

Creed, P., W. Patton and L. Prideaux, 2006. Predicting change over time in career planning and career exploration for high school students. J. Adolescence, 30: 377-392.

DOI: 10.1016/j.adolescence.2006.04.003.

Crites, J., 1976. A comprehensive model of career development in early adulthood. Journal of Vocational Behavior, 9, 105-118. 
Creswell, J.W., 2003. Research Design: Qualitative, Quantitative and Mixed Methods Approaches. 1st Edn., Sage Publications, Inc., Thousand Oaks, California, ISBN-10: 0761924426, pp: 246.

Gati, I. and T. Amir, 2006. Facets of career decisionmaking difficulties. Brit. J. Guidance Counsel., 34: 483-503. DOI: 10.1080/03069880600942608.

Gupta, N. 1989. Indian Adaptation of Crites Career Maturity Inventory (CMI). National Psychological Corporation, Agra.

Hagner, D. and P.R. Salomone, 1989. Issues in career decision making for workers with developmental disabilities. Career Dev. Q., 38: 148-159. DOI: 10.1002/j.2161-0045.1989.tb00417.x

Kerka, S., 1998. Career development and gender, race and class. Report No. EDO-CE-98-199, Office of Educational Research and Improvement (ED), Washington D.C.

Lindstrom, L., B. Doren, J. Metheny, P. Johnson and C. Zane, 2007. Transition to employment: Role of the family in career development. Except. Child., 73: 347-366. 10.1177/001440290707300305

Luzzo, D.A., 1995. The relative contributions of selfefficacy and locus of control to the prediction of career maturity.. J. Coll. Stud. Dev., 36: 61-66.

Mellard, D.F. and J.S. Hazel, 1992. Social competencies as a pathway to successful life transitions. Learn. Disability Q., 15: 251-271. DOI: 10.2307/1511317

Miles, J., 2008. The impact of a career development programme on career maturity and academic motivation. M.A. dissertation, Fort Hare University, East London.

Minskoff, E.H., 1994. Postsecondary Education and Vocational Training: Keys to Success for Adults with Learning Disabilities. In: Learning Disabilities in Adulthood, Gerber, P.F. and H.B. Reiff (Eds.) andover Medical, Boston. MA., pp: 111-120.

Morrow, L.M., 1995. Family Literacy: Connections in Schools and Communities. International Reading Association Inc., New Brunswick, NJ.

Ohler, D.L., E.M. Levinson, and W.F. Barker 1996. Career maturity in college students with learning disabilities. Career Dev. Q., 44: 278-288.
Powell, D.F. and D.A. Luzzo, 1998. Evaluating factors associated with the career maturity of high school students. Career Dev. Q., 47: 145-158.

Salami, S.O., 2008. Gender, identity status and career maturity of adolescents. J. Soc. Sci., 16: 35-49.

Savickas, M.L., 1984. Career maturity: The construct and its measurement. Vocat. Guidance Q., 32: 222-231. DOI: 10.1002/j.2164-585X.1984.tb01585.X

Schimitt-Rodermund, E. and R.K. Silbereisen, 1998. Career maturity determinants: Individual development, social context and historical time. Career Dev. Q., 47: 16-31. DOI: 10.1002/j.2161-0045.1998.tb00725.x.

Swanson, C., 2008. Special education in America: The state of students with disabilities in the nation's high schools. EP Research Center.

Szymanski, E.M. and D.B. Hershenson, 1998. Career Development of People with Disabilities: An Ecological Model. In: Rehabilitation Counseling: Basics and Beyond, Parker, R.L. and E.M. Szymanski (Eds.), PRO-ED, Austin, TX., pp: 327-378.

Tashakkori, A. and C. Teddlie, 1998. Mixed Methodology: Combining Qualitative and Quantitative Approaches. 1st Edn., Sage, Thousand Oaks, CA., ISBN-10: 0761900713, pp: 185.

Taylor, K.M. and N.E. Betz, 1983. Applications of selfefficacy theory to the understanding and treatment of career indecision. J. Vocat. Behav., 22.

USDJ, 1991. American with Disability Handbook. U.S. Government Printing Office, Washington, D.C.

Van Reusen, A., C.S. Bos, J.B. Schumaker and D.D. Deshler, 2015. The Self-Advocacy Strategy: For Enhancing Student Motivation and Selfdetermination: An Education and Transition Planning Process. 1st Edn., Edge Enterprises, Lawrence, KS., pp: 216.

WHO, 1976. International classification of impairments, disabilities and handicap: A manual of classification relating to the consequences of disease. World Health Organisation. 